\title{
Så smækker vi kassen i!
}

\section{- sanktion som redskab i kommunernes håndtering af kontanthjælpsmodtagere}

\author{
Dorte Caswell \& Matilde Høybye-Mortensen
}

Denne artikel handler om økonomiske sanktioner over for kontanthjælpsmodtagere i jobcentrene. Der har i de seneste år været en markant vækst i antallet af sanktioner over for kontanthjælpsmodtagere. Det gælder også borgere, der er kategoriseret som havende problemer ud over ledighed. Med udgangspunkt i to relativt hyppigt sanktionerende kommuners praksis vises, hvordan kommunerne retfærdiggør deres sanktionspraksis gennem henvisning til, at der er tale om en 'skal-lovgivning'. Minimering af det socialfaglige skøn retfærdiggøres gennem argumenter om borgerens retssikkerhed. Samtidig finder vi tegn på organisatorisk hykleri blandt andet i form af, at det socialfaglige individuelle skøn fremhæves som vigtigt samtidig med, at det overflødiggøres, idet den kommunale organisering understøtter en automatisering af udstedelsen af sanktioner over for den enkelte kontanthjælpsmodtager. Der bygges på Brunssons teori om organisatorisk adfærd.

$I^{2}$ Danmark har personer, der modtager kontanthjælp, pligt til at udnytte deres arbejdsmuligheder aktivt og tage imod rimelige tilbud om arbejde. De har desuden pligt til at møde op til samtaler og deltage i tilbud om aktivering. Overholdes disse krav ikke, kan det udløse en økonomisk sanktion. En sanktion kan både betyde, at kontanthjælpen nedsættes med et på forhånd defineret beløb, at der trækkes et beløb svarende til de dage, forseelsen strækker sig over, og i mere alvorlige tilfælde helt bortfald af ydelsen $^{1}$. I sager, der vedrører kontant- og starthjælpsmodtagere med problemer ud over ledighed, er det kommunens konkrete vurdering, hvorvidt den enkelte ikke står til rådighed. Der hvor sanktion ikke fremmer rådigheden hos kontanthjælpsmodtageren, skal der ikke gives en sanktion (VEJ 2010).
Der er altså et kommunalt skønsmæssigt råderum i forhold til anvendelse af sanktioner over for kontanthjælpsmodtagere, hvilket må antages at kunne forklare noget af den store variation i kommunernes anvendelse af sanktion (www.jobindsats.dk).

I figur 1 på næste side er den kommunale organisering omkring sanktionerne skitseret.

\section{Organisatorisk struktur}

Den generelle organisering i landets jobcentre er, at jobcentrets sagsbehandlere laver en vurdering af den lediges beskæftigelsespotentiale, når den ledige ansøger om kontanthjælp. Vurdering angives med en matchkategori fra 1 til 3 (1 jobklar, 2 indsatsklar og 3 midlertidig passiv). Jobcentrets sagsbehandlere varetager endvidere de 
Figur 1. Organisering af tildeling af sanktion

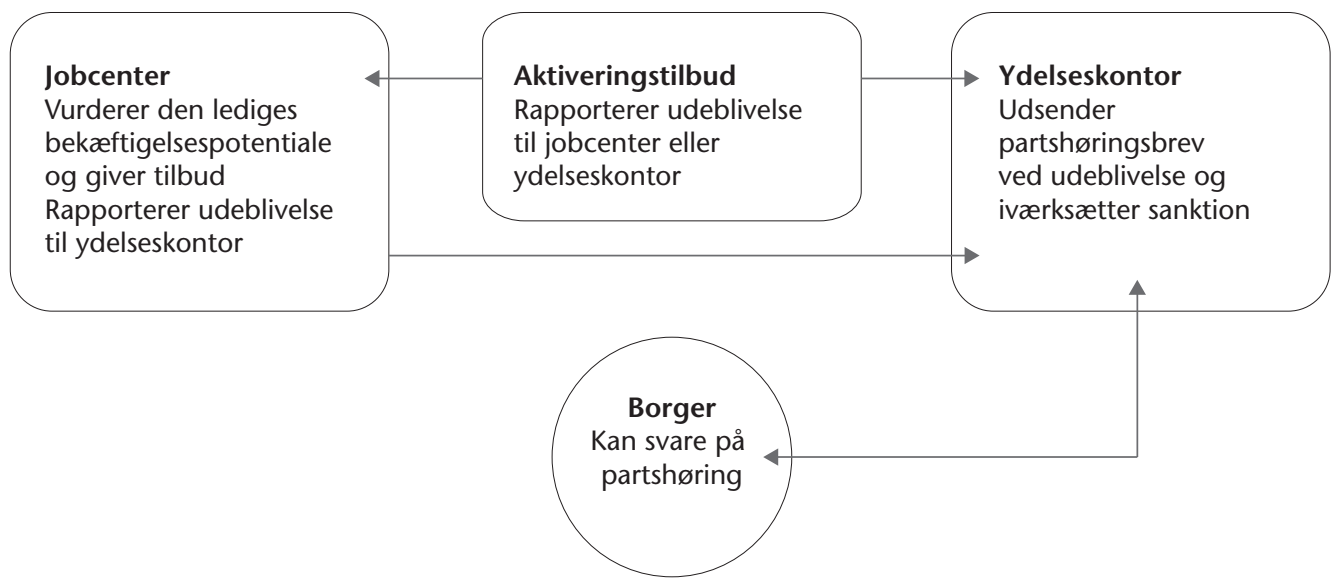

opfølgende samtaler og visiterer kontanthjælpsmodtageren til tilbud (fx aktivering eller behandling). Der er lovkrav om, at der skal foretages opfølgende samtaler minimum hver tredje måned. Udebliver kontanthjælpsmodtagen fra samtale eller afviser tilbud, kan det medføre en sanktion. Som udgangspunkt skal alle matchgrupper sanktioneres efter ens principper.

Er kontanthjælpsmodtageren tilknyttet et tilbud, er det tilbuddet, der registrerer fremmøde, og som rapporterer udeblivelse til jobcentret eller ydelseskontoret (hvem der rapporteres til afhænger af den lokale organisering). Tilbud dækker her over både tilbud efter Lov om Aktiv Beskæftigelsespolitik og andre beskæftigelsesfremmende foranstaltninger.

Det er fastsat som central regel, at en særskilt afdeling af kommunens forvaltning alene skal varetage beskæftigelsesindsatsen $^{2}$. Dette betyder, at jobcentret skal være adskilt fra ydelseskontoret i kommunerne. Således er det jobcentret, der vurderer borgerens beskæftigelsespotentiale, og ydelseskontoret, der tager stilling til, om borgeren er berettiget til forsørgelsesydelser, varetager udbetaling af samt tilbageholder ydelser (=sanktion) (KL 2010). Formålet er at sikre, at der alene tales beskæftigelsesindsats i jobcentret og pengeanliggender på ydelseskontoret. Hvordan den specifikke arbejdsdeling (fx omkring udsendelse af partshøringsbreve) er mellem jobcenter, tilbud og ydelseskontor afhænger af lokale beslutninger og forhold. Arbejdsmarkedsstyrelsen har i juni 2011 fået udarbejdet en rapport om afbureaukratisering af rådigheds- og sanktionsregler (Arbejdsmarkedsstyrelsen 2011b). Her anbefales en ændring i arbejdsdelingen mellem jobcenter og ydelseskontor, idet de skriver, at

"... i tilfoelde, hvor det drejer sig om sanktioner på grund af manglende medvirken $i$ beskoeftigelsesindsatsen, kunne det voere relevant at justere arbejdsdelingen. På dette felt hoenger beskaftigelsesindsats og penge nemlig uløseligt sammen" (Arbejdsmarkedsstyrelsen 2011b, 37).

\section{Forskning på området}

I det seneste årti har tilgangen til beskæftigelsesindsatsen forrykket sig (Caswell m.fl. 2010). Lovændringerne har indbefattet, at grupper har fået deres forsørgelsesgrundlag reduceret (via starthjælpen, kontanthjælpsloftet, 500 kr.-nedsættelsen, 
300-timers-reglen ${ }^{3}$ og ungesatsen) og deres rådighedsforpligtelse skærpet. Eksempelvis får alle kontanthjælpsmodtagere med problemer ud over ledighed ret og pligt til aktivering én gang om året, som følge af $\mathrm{Ny}$ chance til alle fra $2005^{4}$. Parallelt med dette er der kommet et øget fokus på sanktioner over for kontanthjælpsmodtagere. En ny undersøgelse fra AKF (Caswell m.fl. under udgivelse) viser, at ca. $11 \%$ af alle kontanthjælpsmodtagere rammes af økonomiske sanktioner. Mens det generelle billede er, at sanktionerede kontanthjælpsmodtagere helbredsmæssigt har det bedre end de ikke-sanktionerede, så er de sanktionerede ikke uden problemer. $15 \%$ af de langvarige kontanthjælpsmodtagere under 25 år har en psykiatrisk diagnose, og $38 \%$ af denne gruppe får psykofarmaka. For de over 25-årige er de tilsvarende tal $12 \%$ med diagnose, og $40 \%$ får psykofarmaka. Allerede forud for kommunalreformen i 2007 blev det fremført, at der var en risiko for, at de svageste ledige kunne blive klemt, når fokus i højere grad blev rettet mod sanktioner og disciplinering (Caswell \& Damgaard 2006).

Forskningen om brugen af økonomiske sanktioner over for arbejdsløse har især lagt vægten på at analysere effekten af sanktionerne og har koncentreret sig om den beskæftigelsesmæssige effekt ${ }^{5}$ (Svarer 2007; Svarer 2010; Arbejdsdirektoratet/Qureshi 2010). Disse undersøgelser konkluderer, at sanktioner i væsentlig grad bidrager til at få folk væk fra offentlig forsørgelse. Det er dog værd at bemærke, at undersøgelserne udelukkende fokuserer på arbejdsløse, der ikke har problemer ud over ledighed. Svarers publikationer fokuserer specifikt på dagpengemodtagere og Arbejdsdirektoratet/Qureshis på arbejdsmarkedsparate kontanthjælpsmodtagere. Konklusionerne peger på, at sanktioner synes at have størst effekt på mænd og de mest arbejdsmarkedsparate. Alligevel peger bl.a. Svarer på, at resultaterne indikerer, at
“... svagere arbejdsløse også påvirkes af sanktioner, og $i$ forhold til nogle karakteristika reagerer de faktisk stoerkere end mere arbejdsdygtige grupper" (Svarer 2007, 21, egen oversættelse).

De danske effektstudier trækker i væsentlig grad på et hollandsk studie af Van den Berg m.fl. (2004). Pointen om de svagere ledige kobles specifikt an til det hollandske sanktionsstudie, der tager empirisk udgangspunkt i kontanthjælpsmodtagere. Men ligesom tilfældet er for de danske undersøgelser, er fokus her på de borgere, der er kategoriseret som arbejdsmarkedsparate, og som har arbejdsmarkedserfaring. Når Svarer argumenterer for, at 'svagere ledige' også vil reagere på sanktioner ved at forlade offentlig forsørgelse, er det altså stadig kun inden for de arbejdsmarkedsparates rækker, der er videnskabeligt belæg for dette argument. De senere års forskning vedrørende økonomiske incitamenter over for start- og kontanthjælpsmodtagere giver grund til at antage, at en reduktion eller fratagelse af forsørgelsesgrundlaget har mindre positiv beskæftigelseseffekt, når personerne er sårbare og/eller har problemer ud over arbejdsløshed. Ejrnæs m.fl. (2010) har undersøgt levevilkår og coping blandt modtagere af de laveste sociale ydelser. Her påvises det på den ene side, at en nedsættelse af ydelsen for de ressourcestærke medfører en mere aktiv og succesfuld jobsøgning, mens det på den anden side, for de ressourcesvage borgere, medfører modløshed og opgivenhed hos den enkelte at få nedsat ydelsen.

\section{Artiklens teoretiske ramme}

De hidtidige undersøgelser af sanktion af ledige har altså primært bestået af statistiske analyser af sammenfald mellem sanktion og afgang fra offentlig forsørgelse. Vi vil i denne artikel anlægge et organisations- 
teoretisk perspektiv og på den vis komme tættere på processerne i jobcentret, der leder frem til, at en kontanthjælpsmodtager sanktioneres. Som nævnt tidligere har jobcentrene et vist skønsmæssigt råderum i forhold til at vurdere, i hvilken udstrækning den enkelte borgers rådighed vil blive fremmet af sanktioner og derfor skal sanktioneres, og der er en varians mellem forskellige jobcentres brug af sanktionsmuligheden. I artiklen spørges, hvordan de kommunale jobcentre håndterer sanktion som redskab i beskæftigelsesindsatsen, og hvordan kommuner, der sanktionerer meget, får sanktionspraksis, lovgivning og politiske målsætninger til at mødes. Det besvares med en analyse af to jobcentres specifikke organisering samt af deres forståelse af rådighed og retssikkerhed i relation til anvendelsen af sanktioner. Teoretisk trækker artiklen på Nils Brunssons teori om retfærdiggørelse og organisatorisk hykleri (1993; 2002).

Jobcentrene er offentlige organisationer, der hører under kommunerne, men samtidig er kraftigt regulerede fra statens side. Kommunalpolitikerne har således relativt lidt råderum til at bedrive beskæftigelsespolitik eller organisere indsatsen anderledes. Kommunale ledere på det beskæftigelsespolitiske område orienterer sig i høj grad mod det regionale og centrale niveau (bl.a. beskæftigelsesregionen og Arbejdsmarkedsstyrelsen) blandt andet i kraft af den styring, der sker af jobcentrene. Et centralt element i denne styring er de økonomiske incitamenter, der betyder, at kommunerne mister en del af deres refusion fra staten, hvis ikke jobcentret overholder rettidighed for afholdelse af samtaler m.m. (HøybyeMortensen 2011). Endvidere orienterer jobcenterlederne sig mod den ranking af jobcentre, der løbende offentliggøres af Arbejdsmarkedsstyrelsen på Jobindsats.dk. Her kan man følge med i, hvilke kommuner og hvilke jobcentre der sanktionerer og aktiverer mest. Det er derfor meningsfuldt at anskue jobcentrene som organisatoriske enheder, der agerer i forhold til signaler og regulering fra et nationalt felt.

Brunsson (1993) hævder, at den gængse antagelse om, at ideer fører til og kontrollerer handlinger, er problematisk. Man kan betragte dette teoretiske perspektiv som et svar på en klassisk implementeringsproblematik: Hvordan kan det være, at politik ofte er vanskeligt at omsætte til konkret praksis? Lipsky (1980) skrev i sit klassiske værk om de dilemmaer, der opstår, når frontlinjemedarbejdere i velfærdsstaten skal omsætte politik til praksis. Han viser bl.a., hvordan frontlinjepraktikere, såsom socialarbejdere og lærere, anvender forskellige copingstrategier i forsøget på at håndtere diskrepansen mellem de behov og krav, de møder i kontakten med borgerne og de politiske målsætninger på området. Rothstein har kaldt diskrepansen mellem de politiske ideer og udførte handlinger, for 'demokratiets sorte hul' (1994). Brunssons tilgang er mindre normativ kritisk end ovennævnte forfattere, der peger på, at coping er problematisk, og at demokratiets sorte hul er uønsket. Brunsson argumenterer i stedet for, at der er et iboende dilemma mellem ideer (tale og beslutninger) og handlinger, og for at dette dilemma må håndteres af organisationer. Han hævder, at der er tale om en organisatorisk arbejdsdeling. Ideer formuleres på ét niveau og omsættes til beslutninger. Disse ideer og beslutninger skal dernæst kommunikeres til et andet niveau, nemlig der hvor handlinger finder sted. Brunssons pointe er, at ideernes verden og handlingens verden er vidt forskellige, og det kan være meget vanskeligt at forene de to. Forskellige problemer affødes af det uforenelige ved ideernes og handlingernes verden (Brunsson 1993, 490). Dels betyder det, at det, der kan tales om, ikke nødvendigvis kan omsættes 
til handling. Det betyder også, at det, der kan gøres, ikke altid kan siges. Denne diskrepans påvirker mulighederne for at opnå konsistens mellem ideer og handlinger. Ideer kan samtidig udvikle sig forskelligt afhængigt af konteksten. Hvis konteksten betoner betydningen af ideer, vil de udvikle sig i én retning, mens de vil udvikle sig anderledes i kontekster, hvor handling står centralt. Vi vil argumentere for, at jobcentrene udgør kontekster, hvor handling står centralt, bl.a. fordi den kommunale økonomi i høj grad er hængt op på de konkrete handlinger, jobcentret foretager.

Der er ifølge Brunsson forskellige måder, hvorved organisationer kan bygge bro mellem ideer og handlinger. Den første løsning er retfoerdiggørelse: Her søger organisationer at forsvare planlagte eller udførte handlinger ved at retfærdiggøre dem gennem tale. Det betyder samtidig, at handlinger, der ikke kan tales om, heller ikke kan retfærdiggøres. Den anden løsning er organisatorisk hykleri: Her benytter organisationen sig af hyklerisk adfærd i form af at sige ét, men gøre noget andet. Hykleri og retfærdiggørelse bliver af Brunsson betragtet som en løsning på organisationens dilemma frem for som et problem og som noget, der kan være uundgåeligt i en organisation, der har en daglig drift at varetage, som $\mathrm{fx}$ kontinuerlig betjening af massevis af borgere. Hykleri har adskillige fordele frem for retfærdiggørelse. Frem for at problematiske handlinger forsvares (retfærdiggørelse), accepteres opdelingen mellem ideer og handlinger, således at det, der skal siges, bliver sagt, og det, der skal gøres, bliver gjort, også selvom der er uoverensstemmelse mellem de to. Man kan sige, at Brunssons begreber om retfærdiggørelse og hykleri kobler an til Lipskys begreber om coping, men hvor Lipsky taler om coping på et individuelt niveau (hos frontlinjemedarbejderen), så udgør retfærdiggørelse og hykleri organisatoriske copingstrategier.

\section{Retfærdiggørelse og hykleri i jobcentre}

Selvom Brunssons teoretiske univers er abstrakt, så er der umiddelbare koblinger til de udfordringer, vi ser i kommunernes bestræbelser på at få jobcentrenes sanktionspraksis over for kontanthjælpsmodtagerne til at harmonere med de politiske ideer, der lanceres på nationalt niveau.

Figur 2. Ideernes verden og handlingernes verden set $i$ forhold til sanktioner

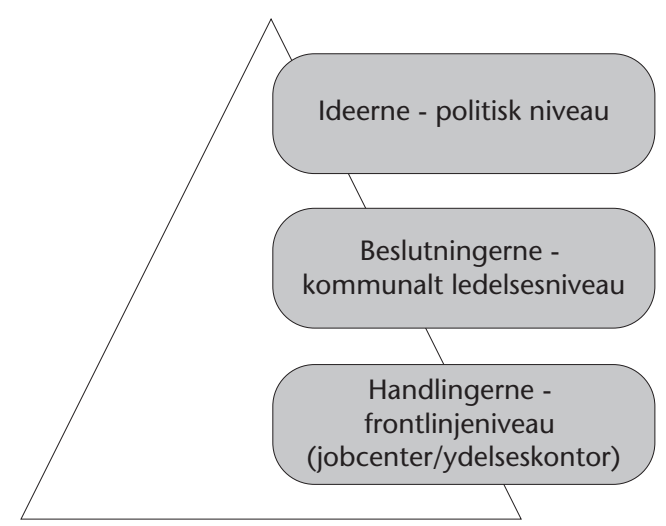

Figur 2 illustrerer, hvordan vi oversætter Brunssons begreber til den specifikke analyse af økonomiske sanktioner over for kontanthjælpsmodtagere. Vores empiriske fokus er for det første den del af ideernes verden, hvori centrale ideer om sanktioner udtrykkes på et nationalt plan. Vi trækker på en række skriftlige dokumenter (lovgivning, vejledninger og udmeldinger fra centralt hold, som fx Arbejdsmarkedsstyrelsen), som gengiver de politiske ideer på området. En anden del af ideernes verden foregår lokalt. Her fokuserer vi på, hvordan der tales om sanktioner på det kommunale ledelsesniveau, og hvordan beslutninger, der er truffet lokalt, formidles til medarbejdere.

Vores analyse retter også fokus mod handlingernes verden. Det vil sige konkrete handlinger, der fører til, at en borger modtager en økonomisk sanktion eller ej. Her er 
tale om handlinger, som udføres af frontlinjemedarbejdere i kommunale organisationer, såvel jobcentre som ydelseskontorer, der begge har bemyndigelse (og forpligtelse) til at sanktionere kontanthjælpsmodtagere. Der findes på det kommunale plan et vist frirum til at organisere procedurerne omkring sanktionering. Den praktiske udformning og arbejdsdeling betragter vi som hørende til i handlingernes verden.

\section{Empirisk materiale og analysetilgang}

Artiklen bygger på en undersøgelse om sanktioner på kontanthjælpsområdet, hvor det empiriske materiale er indsamlet og produceret i foråret 2011. Undersøgelsens datagrundlag er kombineret kvantitativt og kvalitativt. I denne artikel tages udgangspunkt i en delmængde af den samlede kvalitative empiri, nemlig semistrukturerede interview med ledelse og frontlinjemedarbejdere $\mathrm{i}$ to jobcentre (fem interview pr. kommune). Brugen af interviewmateriale bygger på en feltteoretisk forståelse, hvor interviewudsagn antages at komme fra en position i et felt og være adresseret til andre positioner (Bourdieu 1996). Det betyder, at interviewudsagn betragtes som indlæg i en kamp om at definere, hvordan beskæftigelsesfeltet skal indrettes. Derved giver udsagnene viden om, hvordan feltet ser ud fra en given position og viden om, hvilke kapitaler der er i høj kurs på feltet.

Det kvalitative materiale stammer fra to kommuner, der sanktionerer relativt meget set i forhold til jobcentre med sammenlignelige rammevilkår. Disse rammevilkår er hentet fra den klyngeinddeling af kommunerne, som er foretaget i Arbejdsmarkedsstyrelsens opgørelse på jobindsats.dk. Klyngeinddelingen tager udgangspunkt i bl.a. demografisk sammensætning, uddannelsesniveau og erhvervsstruktur. I ca- sene interesserer vi os særligt for faktorer i det kommunale landskab (politik, organisering, praksislogikker, holdninger hos frontlinjemedarbejderen mv.), der kan have betydning for anvendelsen af sanktioner. Vi har valgt at anonymisere disse to kommuner, da de fungerer som cases, der kan kaste lys over generelle mønstre ved hyppig anvendelse af sanktion på et begrebsligt og teoretisk niveau og dermed ikke skal ses som egentlige og udfoldede casestudier af netop disse to kommuners samlede indsats på beskæftigelsesområdet. Det er vores vurdering, at kommunenavne hurtigt kan aflede opmærksomheden fra de analytiske pointer, der kan udledes af casen.

Kommunerne udgør strategiske cases (Yin 2003), der vælges, fordi vi har bestemte forventninger knyttet til den information, der kan uddrages af netop disse cases. Fordi vi ved, at der i disse kommuner anvendes sanktioner i højere grad end i andre kommuner, der har tilsvarende rammevilkår, antager vi, at der gennem studie af disse kommuner kan opnås særlig viden om, hvad der udløser en sanktion. Det er samtidig en instrumentel case (Stake 2003), der er kendetegnet ved, at erkendelsesinteressen primært er rettet mod at opbygge viden om netop anvendelsen af sanktioner, som redskab i kommunal praksis over for de ikke arbejdsmarkedsparate borgere, og ikke kommunens samlede indsats. Interessen er både rettet mod den kommunale praksis og mod, hvordan den enkelte frontlinjearbejder tænker om anvendelse af værktøjet 'sanktion'. Vores analytiske tilgang har indledningsvis været induktiv. Produktionen af det kvalitative materiale har været styret af et stramt empirisk fokus på anvendelsen og forståelsen af de økonomiske sanktioner i de to kommuner. Det empiriske materiale viste sig at rumme en række udsagn, der synes at være i modsætning til hinanden og til det, vi så i lovgivningen. Vi undrede 
os over disse udsagn og ønskede at forstå, hvad der lå bag denne diskrepans. Brunssons begreber virkede oplagte at anvende i dette arbejde. Måske endda så oplagte, at analysen til en vis grad kan synes deduktiv. Reelt har der dog været tale om en bevægelse fra det induktive til det mere deduktive i arbejdet for at forstå, hvordan kommuner, med særligt fokus på de mere sanktionsivrige af slagsen, anvender det råderum, de har i forhold til at sanktionere kontanthjælpsmodtagere.

Analysen tager ikke udgangspunkt i et repræsentativt udsnit af danske kommuner og giver ikke mulighed for at udsige noget generelt om, hvordan danske kommuner anvender sanktioner. Analysen åbner dog mulighed for generaliseringer på et mere teoretisk og begrebsligt niveau, hvor organisatoriske copingstrategier, som vi finder $\mathrm{i}$ disse to kommuner, må antages at kunne genfindes i andre kommuner i større eller mindre udstrækning. Samtidig rummer analysen bud på, hvilke organisatoriske elementer der kan øge sandsynligheden for sanktion, hvilket må antages at have generel gyldighed i en bredere kommunal sammenhæng.

\section{Tre centrale ideer bag sanktioner}

$\mathrm{Vi}$ vil i det følgende præsentere tre centraler ideer, som lovgivningen om anvendelse af sanktioner over for kontanthjælpsmodtagere hviler på:

- Borgeren har forpligtelse til at stå til rådighed for arbejdsmarkedet, og det er kommunens opgave at føre kontrol med dette gennem vurdering i det enkelte tilfælde.

- Retssikkerhedsaspektet er vigtigt, fordi sanktioner kan føre til, at borgeren mister sin forsørgelse, derfor skal borgeren have kendskab til, hvilke handlinger der fører til sanktion.
- Sanktion virker, fordi (trussel om) sanktion fører til, at borgeren handler (fx intensiverer sin jobsøgning, møder op til aktivering eller bliver selvforsørgede).

Disse ideer kan findes formuleret i såvel lovgivningen som den politiske diskurs, og de udgør centrale elementer i det, der 'kan siges' i forhold til anvendelsen af økonomiske sanktioner over for kontanthjælpsmodtagere. Gennem disse tre ideer udtrykkes bestemte ønsker og normer i forhold til såvel kontanthjælpsmodtagerens som kommunens adfærd. Brunsson påpeger, at ideernes rolle ikke så meget handler om at afgøre, hvad der skal gøres, men langt mere om, at ideerne skal udtrykke bestemte værdier, guidelines kan man sige i forhold til, hvor organisationen ønskes at bevæge sig hen (Brunsson 1993, 491).

Hvis vi starter med ideen om ret og pligt på kontanthjælpsområdet, så et det en central idé i forhold til anvendelsen af økonomiske sanktioner over for kontanthjælpsmodtagere, at borgeren er forpligtet til at stå til rådighed. Denne rådighedsvurdering foretages af kommunen. Det betyder, at kommunen er forpligtet til i hvert enkelt tilfælde, de overvejer en sanktion, at vurdere borgerens rådighed. I forhold til de borgere, som har problemer ud over ledighed, hedder det, at:

“... kommunen skal vurdere, om der i det enkelte tilfaelde foreligger andre forhold end de $i$ stk. 4 noevnte 6 , der kan begrunde, at den pågoeldende ikke har pligt til at udnytte sine arbejdsmuligheder" (§ 13 i Lov om aktiv socialpolitik).

Derudover understreges det i vejledningen, at i tilfælde "hvor en sanktion ikke fremmer rådigheden hos kontanthjoelpsmodtageren, skal der ikke gives en sanktion" (vejledning til lov om aktiv socialpolitik). I loven præsenteres 
en generel idé om, at kontanthjælpsmodtagere har en forpligtelse til at stå til rådighed. Rådighedsforpligtelsen præciseres i lovgivningen for det første til, at borgeren aktivt skal udnytte sine arbejdsmuligheder, for det andet skal deltage i tilbud efter lov om aktiv beskæftigelsesindsats og for det tredje medvirke i beskæftigelsesfremmende foranstaltninger.

Kontanthjælpsmodtagere kategoriseres som nævnt tidligere i tre kategorier ( 1 jobklar, 2 indsatsklar og 3 midlertidig passiv). Hvor de borgere, som er kategoriseret som 1'ere, forventes at stå til rådighed for arbejdsmarkedet, så er det ikke tilfældet for 2'erne og 3'erne. Det betyder dog ikke, at 2'erne og 3'erne ikke mødes med krav om rådighed. Hvis en borger er vurderet at være klar til en indsats, så har borgeren pligt til at stå til rådighed for denne indsats og de krav, den rummer. Det betyder, at den kommunale fortolkning af 'tilbud' og 'beskæftigelsesfremmende foranstaltninger' får betydning for, hvordan rådighedskravet udmøntes. Borgere, som er kategoriseret som 3'ere, er vurderet til ikke at være i stand til at modtage aktive tilbud. De kan dermed heller ikke sanktioneres for udeblivelse fra eller afvisning af disse (Arbejdsmarkedsstyrelsen 2009). Definitionen af 'beskæftigelsesfremmende tilbud' er dog særdeles bred og rummer i nogle kommuner eksempelvis metadonbehandling og tilbud, der har til formål at lære borgeren varetagelse af egen hygiejne. Bagkanten af, hvad der kan rummes inden for det 'beskæftigelsesfremmende', synes nærmest at være ikke eksisterende ud fra en generel argumentation om, at hvis det givne problem ikke adresseres, så har den pågældende borger i hvert fald ingen chancer for at få et job. Når rådighedsbegrebet fortolkes bredt, betyder det samtidig, at sanktion kan anvendes over for alle tre matchgrupper. I en mail fra Arbejdsmarkedsstyrelsen bekræftes det, at 3'erne godt kan deltage i 'beskæftigelsesfremmende foranstaltninger' og sanktioneres, hvis de udebliver eller afviser (Arbejdsmarkedsstyrelsen 2011a).

En anden idé, der står centralt i forhold til sanktioner, er borgerens retssikkerhed. I Danmark er det en grundlovssikret rettighed, at velfærdsstaten yder økonomisk understøttelse til borgere, der ikke kan forsørge sig selv og sine (jf. Grundlovens § 75, stk. 2). Et element i de nye sanktionsregler, som regeringen vedtog i maj 2009, er, at borgeren kan blive sanktioneret med ophør eller krav om tilbagebetaling af kontanthjælpen ${ }^{7}$. Lovgivningen på området er tæt knyttet til centrale principper om borgerens retssikkerhed og temaet om retssikkerhed står centralt i forhold til anvendelse af sanktioner. I Ankestyrelsens praksisundersøgelse fra januar 2011 hedder det blandt andet, at den kommunale praksis må

"... ses i lyset af den store betydning, en sanktion efter de nye regler $i$ aktivloven kan have for borgeren og dennes families økonomiske situation. Da der er tale om hjoelp til forsørgelse og det nederste sikkerhedsnet, har lovgiver fundet det saerligt vigtigt at indfore regler, der sikrer, at borgeren er bekendt med konsekvensen af udeblivelser mv." (Ankestyrelsen 2011, 5).

Loven opstiller derfor en række krav for at give borgeren retsgaranti. Det er krav om, at borgeren skal vejledes grundigt af kommunen forud for sanktion. Der er krav om, at kommunen skal oplyse borgerens sag tilstrækkeligt forud for anvendelse af en sanktionsparagraf. Det er et krav, at borgeren skal partshøres i forhold til den hændelse, der er årsag til sanktionen, og samtidig er kommunen forpligtet til at give borgeren klagevejledning.

Den tredje idé, der kan siges og bliver sagt, er, at sanktion virker. Ifølge en artikel 
i Danske Kommuner opfordrer Arbejdsmarkedsstyrelsen direkte kommunerne til at spare penge gennem brug af sanktioner:

"... kommunerne kan spare penge ved at benytte sig af sanktioner. Sanktionerne fører til, at de ledige i højere grad søger job, og dermed sparer kommunen kontanthjoelp" (Arbejdsmarkedsstyrelsen i Danske Kommuner nr. 14 2011, 42).

Ideen om, at (truslen om) sanktion eller aktivering fører til øget jobsøgning og derved beskæftigelse, har stået centralt i den beskæftigelsespolitiske bevægelse hen imod en strammere 'work first'-regime. Denne udvikling har vi set internationalt (Lødemel \& Trickey 2001; Torfing 2004), men den kan i høj grad også genfindes i en dansk kontekst. Caswell (2005) har argumenteret for eksistensen af en række forskellige måder at tænke og handle på (praksislogikker) i socialt arbejde på beskæftigelsesområdet. En af disse logikker er en sanktionerende praksislogik, der grundlæggende er disciplinerende. Det primære mål inden for denne logik er at få borgeren gjort selvforsørgende så hurtigt som muligt. For at sikre dette anvendes sanktioner, der kan have forskellig karakter: kontrolforanstaltninger, trusler om sanktioner og faktiske sanktioner, hvor ydelsen tilbageholdes eller reduceres. Denne logik læner sig op af en 'work first'tankegang, hvor det primære mål er at få klienten ud af offentlig forsørgelse hurtigst muligt. Den sanktionsorienterede logik er ofte blevet problematiseret, og bl.a. Larsen m.fl. (2001) har peget på, at

"... en ensidig fokusering på her-og-nu-arbejdsmarkedsrelevans af aktiverings- og uddannelsestiltag er problematisk, fordi man derved springer over de mellemregninger (loerings- og selvvaerdsrum), der for mange langtidsledige kan voere afgørende for at styrke deres langsigtede handlingskompetencer" (Larsen m.fl. 2001, 157).

Den sanktionsorienterede praksislogik har ændret sig noget over tid. Kravene til borgeren er gradvist blevet øget. Det betyder samtidig, at de krav, borgere skal leve op til for at modtage kontanthjælp, er skærpet. Dermed er der også større mulighed for sanktioner.

Hasenfeld m.fl. (2004) argumenterer også for, at der eksisterer en særlig sanktionslogik og peger på, at anvendelse af sanktioner over for modtagere af velfærdsstatslige ydelser læner sig op ad en adfærdslogik, der er baseret på to præmisser. For det første, at når klienten stilles over for en trussel om sanktion, så er han eller hun i stand til at rette sig efter de krav, der stilles fra velfærdssystemets side. Det betyder også, at når klienten ikke retter sig efter disse krav, kan det fortolkes som et udtryk for manglende motivation eller utilstrækkelig økonomisk incitament til at efterleve disse krav. For det andet, at klienterne kender reglerne og er i stand til rationelt at beregne den risiko, der er forbundet med ikke at rette sig efter disse regler.

I det følgende vil vi bevæge os fra ideernes verden til handlingernes verden. Vi vil se nærmere på, hvordan de centrale ideer om rådighed, retssikkerhed og sanktion oversættes til konkrete handlinger i kommunerne. Vi starter med at se på det organisatoriske niveau, og hvordan jobcentrene anvender det råderum, de har, i forhold til at anvende sanktion som virkemiddel over for kontanthjælpsmodtagerne, med særligt fokus på, hvordan organiseringen i de to casekommuner bidrager til det høje antal sanktioner netop her. Dernæst kommer en analyse af, hvordan hensynet til retssikkerhed kan anvendes som retfærdiggørelse, og hvordan jobcentrets vurdering af eget skønsmæssigt råderum kan forstås som organisatorisk hykleri. 


\section{Hvordan bidrager organiseringen lokalt til flere sanktioner?}

Som det fremgår af næste afsnit, synes selve kompetencefordelingen mellem især jobcenter og ydelseskontor at have stor betydning for, om der bliver sanktioneret meget. Det betyder, at jobcenterledelsen kan bruge den interne organisering i jobcentret som et redskab, hvis de ønsker nemt at kunne bruge sanktion som et redskab i beskæftigelsesindsatsen.

Grundlæggende ligner de to casekommuner den generelle organisatoriske model, vi viste i figur 1, men der er tilføjelser og justeringer lokalt, der synes at bidrage til den hyppigere brug af sanktioner over for kommunens kontanthjælpsmodtagere. Vi vil se nærmere på nogle af de organisatoriske elementer, der kan tillægges betydning $\mathrm{i}$ forhold til sanktionshyppigheden $\mathrm{i}$ det, Brunsson kalder handlingens verden.

Selvom der fra Arbejdsmarkedsstyrelsens side argumenteres for, at kategoriseringen af kontanthjælpsmodtagerne er enkel, præcis og ubureaukratisk (Arbejdsmarkedsstyrelsen 2009), så er der fortsat variation kommunerne imellem i forhold til, hvordan borgerne kategoriseres. Tidligere forskning har vist, at der er en tendens til, at sagsbehandlere matcher borgerne højt. At man er "arbejdsmarkedsparat, indtil det modsatte er bevist" (Madsen m.fl. 2006, 9). Et højt match har betydning for, i hvilken udstrækning borgere kan sanktioneres. Det kan med andre ord være en del af beviset for, at borgeren er matchet for højt, at vedkommende ikke lever op til de krav, der stilles om at stå til rådighed og dermed sanktioneres. I kommune B siger afdelingslederen:

"Vi matcher ikke 2'ere, før vi er sikre. Vores gode 2'ere er sikkert mange af de andres mellemgruppe af 2'ere. Vores dårlige 1'ere er de andres 2'ere. Selvom man har en model at matche fra, er det ikke lige meget, hvor man laegger snittet".

Kommunernes tilbud og anvendelse af aktivering som redskab har også betydning for, hvor mange sanktioner der kan gives. Der synes at være sammenfald mellem de kommuner, der aktiverer meget, og de kommuner, der sanktionerer meget (AGENDA 2011, www.jobindsats.dk). Men det er ikke alene graden af aktivering, der har betydning for antallet af sanktioner. Også typen af tilbud har betydning. Loven foreskriver, at $\S 41 \mathrm{i}$ lov om aktiv socialpolitik, der indebærer, at kontanthjælpen ophører for såvel borger som ægtefælle, kun kan anvendes, hvis kommunen har et såkaldt 'åbent tilbud'. Et 'åbent tilbud' er et tilbud, hvor der altid er plads til kontanthjælpsmodtageren, og hvor fremmødet bliver registreret ${ }^{8}$. En leder i en af de to casekommuner peger på, at det netop er tilstedeværelsen af et sådant tilbud i kommunen samt den konsekvente anvendelse af samme der kan forklare, hvorfor kommunen ligger så højt i sanktionsstatistikken:

“... hvad gør, at vi kommer så højt op? Jeg tror, at vi kører meget stringent på åbent tilbud. Det er tilbud, man giver, når borgerne ikke ønsker at deltage eller har fravaer med over $50 \%$ i en periode. Så lukker vi kontanthioelpen efter $\$ 39$ i LAS, og giver et åbent tilbud efter $\$ 41$. Så får de kun penge ved at møde op (...) og kun for de timer, der mødes op. Møder de ikke op, får de ingenting" (afdelingsleder kommune B).

Graden af specialisering og kompetencedelingen mellem jobcenter, ydelseskontor og tilbud har ligeledes stor betydning for sanktionsraten. Opsplitningen i funktioner er således, at ansvaret for sanktion er delt mellem flere afdelinger. For det første er der sagsbehandleren i jobcentret, som vurderer, om kontanthjælpsmodtageren kan deltage 
i en aktivitet. Dernæst er der aktiveringsstedet, der indberetter udeblivelsen fra en aktivitet. Endelig er der ydelseskontoret, der foretager sanktionen over for borgeren, men som ingen kontakt har til borgeren. Denne opsplitning i vurdering af, om kontanthjælpsmodtageren kan deltage i en aktivitet, og vurderingen af, om kontanthjælpsmodtageren kan sanktioneres, er et godt eksempel på organisationens måde at opsplitte ansvaret for sanktion på. I kommune $\mathrm{B}$ beskrives organiseringen således:

"... officielt må du ikke lave en regel for et skøn, så det gør vi selvfølgelig heller ikke. Omvendt, så laver vi nogle kompetenceregler - man kan sige, at det vi har gjort i forhold til sanktioneringer, når vi taler fravaer og udeblivelse fra en aktivitet, er, at vi har lavet det sådan, at den slet ikke kommer ind over sagsbehandlerens bord. Altså når en sagsbehandler har visiteret til en aktivitet, så kører selve fremmødedelen mellem aktivitetsstedet og vores ydelseskontor" (Afdelingsleder, Kommune B).

Der er med andre ord indlagt automatik og distance i administrationen af sanktioner.

Denne organisatoriske opsplitning ses faktisk som en forudsætning for at kunne sanktionere. En sagsbehandler fra kommune B fortæller:

"... vi er skarpt opdelt $i$ forhold til, at vi sidder selvfølgelig med sagsbehandlingen, men det er dem [ydelseskontoret] der $i$ sidste ende troeffer afgørelse i forhold til selve sanktioneringen. (...) Vi har en tro på, at ved at adskille det, så er det lidt mere straight. Borgeren kan ikke lige sådan ringe ind til rådgiver og sige: 'det gik ikke lige og sådan noget'. $\mathrm{Nej}$, er man ikke syg, har man ikke fri eller ferie eller barn syg, så er der ikke nogen forklaring på, hvorfor man ikke dukker op i sin aktivering. Den er de per definition mere straight med på et ydelseskontor, som jo ikke sidder og kender borgeren. (...) Men dem vi så sender i tilbud, de skal efterleve de krav, der er $i$ et tilbud med at melde sig syg og alle de der ting. Så vi har en tro på, at det med at adskille det, det faktisk styrker. Det med at stå fast på sanktionsdelen. Vi vil gerne bruge sanktionsdelen, fordi vi tror på, at det $i$ den sidste ende har en trovoerdighedsvoerdi. Når man har sagt 'ja' til at ville i et tilbud og samarbejde omkring det, jamen så er et af kravene også, at man bliver ansvarlig $i$ forhold til at møde op, og hvis man ikke møder op, jamen så er man ansvarlig for at melde sig syg" (Faglig koordinator, kommune B).

Sanktion er i kommune A og B altså gjort til en administrativ praksis. Som nævnt tidligere er sagsbehandleren ude af sanktionsdelen, når det gælder tilbud og foranstaltninger, idet aktiveringsstedet indberetter direkte til ydelseskontoret, der så sanktionerer. Det kan ifølge en sagsbehandler føre til flere sanktioner, fordi:

"... dem der sidder i ydelseskontoret er kontorpersonale, og de kigger meget bare på, jamen - du er udeblevet, du skal troekkes. Hvor jeg tror, at ved at borgeren ringer til sin sagsbehandler, som kender hele borgerens historie, der kan de måske lidt nemmere sige: ok, så går den denne gang. Det er måske lidt nemmere at få sig forhandlet frem til, at de ikke skal troekkes. Jeg tror, der er mere konsekvens [i ydelseskontoret], fordi de kender ikke borgeren, og det er egentlig heller ikke det, de beskaeftiger sig med - hvad alle deres problemer er osv. De kender ikke borgere. De har bare fået en seddel, hvor der står, de er udeblevet, og så skal der traekkes" (Sagsbehandler i jobcentret, Kommune B).

Denne opfattelse harmonerer med, hvad en faglig konsulent på ydelseskontoret i kommune A fortæller: 
"Jeg forholder mig ikke rigtig til, om det er godt eller skidt. Om det virker eller ej [at sanktionere]. Det er noget, der er bestemt, at vi skal, og så gør vi det. (...) Vi skal ikke føle eller toenke over - sådan er det meget på ydelsesområdet - det er sådan lidt mere firkantet og hardcore lovgivning".

Arbejdsdelingen mellem jobcenter, ydelseskontor og tilbud ses altså som meget afgørende i forhold til casekommunernes høje sanktionsrate.

\section{Retssikkerhed er ensartethed og orden i procedurerne}

Som nævnt tidligere er retssikkerhed, herunder borgerens viden omkring hvad der udløser sanktion, og hvad de skal gøre for at undgå det, en afgørende idé i sanktionslogikken. Denne idé søges ligeledes varetaget i form af en bestemt organisering, der betyder, at ydelseskontoret automatisk udsender partshøringsbreve, når borgeren er udeblevet fra et tilbud. At og hvordan jobcentrene foretager partshøring fylder meget i interviewene. Partshøring betyder, at kontanthjælpsmodtageren har mulighed for at reagere på den skriftligt varslede sanktion (partshøringsbrevet), såfremt kontanthjælpsmodtageren mener, der var tale om lovlig udeblivelse (som fx ved indlæggelse). Denne organisering fremmer ifølge en sagsbehandler fra kommune A, kommunens sanktionsrate. Han mener, at grunden til, at kommunen ligger i top med at sanktionere, er, at:

"... det er organiseret bedre. Det er organiseret på den måde, at det kører administrativt. Det er ikke bare tilfoeldigt, om sagsbehandleren får fat ens sag eller ej, og husker det og sådan noget. Altså, det er mere effektivt organiseret, sådan at der bliver sanktioneret, når der skal."
I kommune A er processerne omkring sanktionering altså automatiseret, og sanktionering kan ske rent administrativt.

\begin{abstract}
"Fremmødesedlerne går direkte til administrationsgruppen, der så sanktionerer. Jeg får slet ikke noget at vide. Det er jo hamrende effektivt og smart (...) det er meget mere systematiseret her, så det er derfor, at de [kommunen] ligger så godt i statistikken [har en høj sanktionsrate]" (sagsbehandler, Kommune A).
\end{abstract}

I kommune A er borgerens retssikkerhed noget, der nævnes i forbindelse med sager i Ankenævnet. En medarbejder på ydelseskontoret siger:

"Borgerens retssikkerhed er enormt vigtig for os. Det er jo super aergerligt at ende med at tabe en sag, hvis ikke vi har overholdt retssikkerheden for borgeren."

Der eksisterer en forståelse af retssikkerhed, som bygger på den antagelse, at borgerne forstår det juridiske sprog, og at borgerne er fuldt bevidste om regler, såfremt de har skrevet under på det. I Ankestyrelsens praksisundersøgelse fra 2011 var under halvdelen af de sager, der indgik i undersøgelsen, i overensstemmelse med lovgivning og praksis (Ankestyrelsen 2011). På den baggrund anbefaler Ankestyrelsen bl.a., at kommunerne sikrer, at vejledningen til borgerne er tilstrækkelig forud for en sanktion. Flere sagsbehandlere siger i interviewene, at borgerne kender reglerne om sanktion, også dem der evt. ikke taler dansk. Som teamlederen i kommune A siger:

"Borgerne ved jo godt, de skal stå til rådighed, det har vi forventningsafstemt med dem."

Dette står dog i modstrid med opfattelsen blandt de interviewede borgere. Her fortalte 
borgerne om forvirring, manglende forståelse og undren over en stor del af de sanktioner, de havde modtaget (Caswell m.fl. under udgivelse). Dette stemmer overens med en konklusion fra Arbejdsmarkedsstyrelsens rapport om afbureaukratisering af rådigheds- og sanktionsreglerne. Her hedder det, at det kan være vanskeligt for borgeren at gennemskue reglerne om sanktion og rådighed, blandt andet på grund af

"...de svoert forståelige breve med oplysninger om partshøring, afgørelser og klagemuligheder, hvis den ledige ikke lever op til sine forpligtelser" (Arbejdsmarkedsstyrelsen 2011b).

Da hensynet til borgerens retssikkerhed er en central idé, er det også noget, der kan hentes ind og netop bruges til at retfærdiggøre handlinger. I lovgivningen er det fastslået, at der, især med hensyn til matchgruppe to og tre, skal skønnes i sager om sanktion. Traditionelt har skøn været noget, der skete på sagsbehandlerniveau og $\mathrm{i}$ individuelle sager. I kommune A er skønnet foretaget på ledelsesniveau, hvor det er afgjort og udmeldt, at sanktionsmulighederne skal bruges. Også teamlederen bekræfter, at skønnet er flyttet væk fra den individuelle sagsbehandler og til ledelsesniveau. Dette begrundes med, at det øger retssikkerheden for borgeren:

"Alle medarbejderne gør det her [sanktionerer], og hvis de ikke gør det, så har de også fået at vide, så er det en tjenstlig forseelse, hvis man ikke sanktionerer borgeren. (...) Man kan ikke bare skrive, at 'det var synd for, at ...' - og det er for at sikre borgerens retssikkerhed. Dvs. om du er inde hos mig eller du er inde hos Jesper, så vil du blive håndteret ens" (teamleder, Kommune A).

Her fortolkes retssikkerhed altså primært som ensartethed. At der ikke må være forskel på de forskellige sagsbehandleres praksis. Ledelsens udmelding om, hvordan skønnet skal forvaltes (hvad der kan gøres) bemærkes på sagsbehandlerniveau. En forholdsvis nyansat sagsbehandler udtaler således:

"Jeg er nødt til at vurdere, hvad er standarden her (...) Jeg ville ikke sidde og sanktionere alle, hvis der var en holdning om, at det gør vi ikke" (sagsbehandler, Kommune A).

\section{Kommunal fortolkning af rådighed og mulighed for skøn}

Helt centralt $\mathrm{i}$ forhold til vurderingen af, hvorvidt en kontanthjælpsmodtager er udeblevet uden legitim grund, står vurderingen af vedkommendes beskæftigelsespotentiale, altså matchkategori. Er en kontanthjælpsmodtager kategoriseret som en match 1 eller 2, vurderes vedkommende at kunne stå til rådighed for aktivitet. At denne indledende vurdering giver et korrekt billede af kontanthjælpsmodtagerens formåen udgør en hjørnesten i jobcentrenes retfærdiggørelse af deres sanktionspraksis. Det retfærdiggør også, at den enkelte sagsbehandler kan fratages skønsmuligheden, når det gælder sanktion som følge af udeblivelse. Teamlederen fra kommune A beskriver det således:

"Som udgangspunkt synes jeg ikke, man burde have lov til at skønne. Fordi det gør det simpelthen så svoert for rådgiveren nogle gange. Altså ulovlig udeblivelse, er ulovlig udeblivelse. (...) Ud fra matchgruppen har man tilbudt dem et forløb, som de godt kan deltage $i$, selv med de måske manglende ressourcer, de har."

Ud over at der her er en forståelse af, at en objektiv vurdering af beskæftigelsespotentialet kan lade sig gøre, udtrykker teamlederen her stor tillid til, at matchkategorise- 
ringen er rigtig og troværdig. Dette står i modsætning til en udbredt jobcenterpraksis, nemlig at matche så højt som muligt (Madsen m.fl. 2006), hvilket betyder, at jobcentret har truffet en beslutning om, at, i tvivlstilfælde, matches til den højeste kategori.

I kommune B, har de den opfattelse, at der slet ikke er mulighed for at skønne i forhold til sanktioner. Afdelingslederen siger:

“... alle dem (...) som enten er beløbsstørrelse eller er varighed, de sanktioner er jo ikke skøn. Der står SKAL i lovgivningen. (...) Vi skønner ikke på den måde, medmindre der selvfølgelig er en legitim årsag til, at man ikke er kommet."

Fortolkningen af loven i kommune B er altså, at retten til at udøve skøn udelukkende gælder vurdering af den legitime grund til fravær og ikke skøn i forhold til, hvorvidt sanktionen fremmer rådigheden. Ifølge Brunsson kan ideer, der ikke kan siges, heller ikke omsættes i beslutninger - og omvendt, kan beslutninger kun udtrykke det, der kan siges. Med det i baghovedet synes det værd at stille spørgsmålet, hvorvidt det, at visse jobcentre sanktionerer mere end loven egentlig tilsiger, er udtryk for, at disse jobcentre bestræber sig på at etablere sammenhæng mellem idé og handling frem for sammenhæng mellem beslutning og handling. Med andre ord, at jobcentret forsøger at få deres handlinger til at harmonere med signaler fra centralt hold (bl.a. fra Arbejdsmarkedsstyrelsen) om, at jobcentrene skal sanktionere mere. Dette er dog netop et signal, der ikke er omsat til mere bindende beslutninger, da det, der kan siges og derfor besluttes lovgivningsmæssigt, fortsat er, at der skal skønnes og tages individuelle hensyn.

Legitimiteten af jobcentrets vurdering af kontanthjælpsmodtagerens rådighed for- klares ved, at det er en 'blød' sagsbehandler, der foretager den. Sagsbehandlerne er dem, der skal levere etiske overvejelser og tage individuelle hensyn. Der er både fra sagsbehandler- og ledelsesside en forestilling om, at sagsbehandlerne i jobcentret er 'bløde' og tager individuelle hensyn til kontanthjælpsmodtageren. Der synes at være et vist belæg for denne forestilling. En medarbejder i jobcentret i kommune A fortæller om en lidt mere lempelig tilgang $i$ forhold til visse grupper borgere:

"Jeg har fx en person, der er udeblevet fire gange. Når en person udebliver, skal vi eftersende information til administrationen [ydelseskontoret], og så er det dem, der sender et partshøringsbrev. Men inden jeg sender informationen til administrationen, så prøver jeg at kontakte dem [kontanthjælpsmodtagerne]. Fordi dem, der normalt udebliver, det er alkoholikere eller folk med psykiske problemer, angst, så de har svoert ved at møde op. Så jeg venter en til to dage, måske ringer jeg telefonisk, og så bagefter informerer jeg administrationen om, at de ikke er mødt op".

Den adfærd afspejler den forventning, ledelsen har til jobcentersagsbehandlerne. Teamlederen siger:

"Vi finder jo et tilbud, der er kvalificeret til borgerens behov. Men vil borgeren så alligevel ikke, så er det mangel på vilje. (...) Det er rigtig svoert [at vurdere om der er tale om mangel på evne eller vilje], men det sker efter nogle samtaler med loegekonsulenten. Jeg har aldrig oplevet nogen, hvor man kan sige, at vi er gået for langt. Det er socialrådgivere, der sidder på pindene, de er rigtig dygtige til at lave en socialfaglig vurdering, vi har høj etik $i$ vores arbejde, høj faglighed. $V i$ sender ikke nogen borgere ud $i$ et forløb inden det er tilrettelagt" (teamleder, kommune A). 
Også afdelingslederen i kommune B fremhæver, at jobcentret laver et individuelt tilpasset forløb, som er strikket sammen, så borgeren kan holde til det, hvilket gør det legitimt at sanktionere ved udeblivelse. Formelt set har sagsbehandleren således mulighed for at lave individuelle faglige skøn. Det er dog her værd at bemærke, at de sagsbehandlere, der skal agere bløde og sikre de individuelle hensyn, vil skulle gøre det $\mathrm{i}$ opposition til både udmeldinger fra politisk nationalt niveau (Beskæftigelsesminister, Arbejdsmarkedsstyrelse) og udmeldinger fra jobcenterledelsen om, at alle kan sanktioneres etc. Det er således sandsynligt, at det kræver en stærk socialfaglig kompetence og integritet at skulle fastholde en vurdering om, at en borger ikke kan stå til rådighed i en organisatorisk ramme, der hælder til et princip om, at alle i udgangspunktet er arbejdsmarkedsparate.

\section{Konklusion}

Vi har i denne artikel beskæftiget os med, hvordan sanktion håndteres som redskab, samt med hvordan hyppigt sanktionerende kommuner får deres sanktionspraksis til at hænge sammen med lovgivning og de centrale ideer på området.

Gennem anvendelse af begreber fra Brunsson har vi i analyserne søgt at bidrage til at kvalificere forståelsen af, hvordan kommuner, der sanktionerer meget, anvender det råderum, de har i forhold til at sanktionere kontanthjælpsmodtagere. Analysen af de to hyppigt sanktionerende kommuner viser, at organiseringen af procedurer og arbejdsdeling mellem jobcenter og ydelseskontor har betydning for de konkrete sanktionshandlinger, der foretages. Når arbejdsdelingen automatiserer håndteringen af sanktionerne, og skønnet forskydes fra frontlinjeniveau til ledelsesniveau, så åbnes muligheden for flere sanktionshandlinger.
Både retfærdiggørelse og hykleri kan identificeres som handlemåder i de to casekommuner. En flittig anvendelse af sanktioner retfærdiggøres blandt andet gennem henvisning til, at lovgivningen er en 'skallovgivning'. Det er med andre ord slet ikke en beslutning, der ligger på kommunalt niveau, at der skal sanktioneres flittigt, men en forpligtelse i forhold til den gældende lovgivning. En anden måde, hvorpå den hyppige anvendelse af sanktion som værktøj retfærdiggøres, er gennem henvisning til borgerens retssikkerhed. Det socialfaglige skøn bliver her defineret som et problem i forhold til borgerens retssikkerhed, da skønnet indebærer en risiko for, at borgere ikke behandles ens. Organisationens hykleri består i, at jobcentrene på handlingsniveau har organiseret sig på en måde, hvor sagsbehandlerne springes over, når der skal sanktioneres, men på taleniveau hviler organisationen sin legitimitet på, at sagsbehandlerne er i stand til at foretage individuelle og korrekte vurderinger af kontanthjælpsmodtageren, således at organisationen ikke fremstår 'uretfærdig'.

Hvis man har en antagelse om, at organisationer agerer rationelt, opstiller mål og derefter forfølger dem i handlinger, kan det synes dysfunktionelt, at organisationen har en målsætning om at sanktionere alle og en diskurs omkring, at sagsbehandlere er bløde og derfor ikke skal have lov at skønne, samtidig med at det individuelle hensyn til borgeren garanteres af netop den bløde sagsbehandler med 'høj etik', og at sanktioneringen derved ikke er uretfærdig, dvs. ikke rammer kontanthjælpsmodtagere, der ikke kan honorere kravene. Dette kan dog forklares med Brunssons begreber om organisatorisk hykleri, hvor organisationen opnår en ny ligevægt og opretholder sin egen eksistens, netop i kraft af uoverensstemmelse mellem tale, beslutning og handling. 
Hykleri findes dog ikke alene på det kommunale niveau, men kan også findes på et nationalt niveau. I lovgivningen (hvad der kan siges) gøres det klart, at der skal tages individuelle hensyn til borgeren. Der skal kun sanktioneres, hvis det fremmer rådigheden. På handlingsniveauet (det der kan gøres) har Arbejdsmarkedsstyrelsen mulighed for at sanktionere kommunerne økonomisk. Sanktionslogikken er altså ikke alene rettet mod kontanthjælpsmodtagerne men også mod kommunerne. De økonomiske sanktioner kan betyde, at kommunerne har incitament til at tage færre individuelle hensyn i bestræbelserne på at sanktionere meget, for at sikre egen økonomi. Staten fører kontrol med kommunernes sanktionspraksis (bl.a. gennem offentliggørelse af antallet af sanktioner i samtlige kommuner).

Kommunerne kan miste refusion, hvis de sanktionerer forkert (såvel for lidt som for meget), men parallelt med de i lovgivningen fastlagte regler om individuelle hensyn, un- derstreges kommunernes forpligtelse til at sanktionere. Her er fokus på risikoen for, at kommuner sanktionerer for lidt, idet det understreges at refusionen for en udbetalt ydelse (uretmæssig fordi der skulle have været sanktioneret) mistes, hvis ikke kommunen har fulgt rådigheds- og sanktionsreglerne.

Når organisationer benytter sig af retfærdiggørelse og hykleri, er det en måde at opretholde legitimitet på, samtidig med at organisationens drift og overlevelse sikres. Det, der skal siges, bliver sagt, og det, der skal gøres, bliver gjort. Det understreger Brunssons pointe om, at hykleri er en meget effektiv handlemåde. I jobcentrenes tilfælde er det en effektiv løsning på øget brug af sanktioner, idet hykleri tillader jobcentrene at honorere både ideen om, at der skal tages hensyn til den individuelle kontanthjælpsmodtagers formåen, samtidig med at Arbejdsmarkedsstyrelsen og eventuelle egne ønsker om øget brug af sanktion kan praktiseres.

\section{Noter}

1 De centrale paragraffer for sanktion er $\S 36$ (kontanthjælpen nedsættes med en gennemsnitssats pr. dag), § 37 (kontanthjælpen nedsættes med de dage, udeblivelsen strækker sig over) og § 41 (ophør af kontanthjælp også for ægtefælle). Derudover kan der også sanktioneres efter $\S 38$ samt $\S 39 / 40$, Lov om aktiv social politik.

2 § 14 og 15 i Bekendtgørelse af lov om ansvaret for og styringen af den aktive beskaftigelsesindsats, LBK nr. 731 af 15/06/2010.

3 Der senere er blevet ændret til en 450-timers-regel og pr. 1. juli 2011 gennemgår en yderligere stramning.

4 Med 'Flere i arbejde' fra 2002 blev ledige forpligtet til at tage imod "rimeligt arbejde" fra første ledighedsdag og udvise større geografisk mobilitet. Med Ny chance til alle fra 2005 blev det muligt at trække kontanthjælps- modtagere $1 / 3$ i deres ydelse, hvis de melder sig syge og ikke aktivt deltager $i$ at komme tilbage til arbejdsmarkedet, unge mellem 18-25 år med ledighed som eneste problem fik endvidere pligt til at begynde en kompetencegivende uddannelse, og alle ledige med problemer ud over ledighed får ret og pligt til aktivering én gang om året.

5 Beskæftigelseseffekten måles ofte på 'afgang fra arbejdsløshed', hvilket for en stor dels vedkommende vil være til en status som lønmodtager. Gruppen må dog antages også at rumme borgere, som står uden forsørgelse. Mål på beskæftigelseseffekt siger heller ikke noget om, hvilken type beskæftigelse der er tale om, hvor længe borgeren forbliver i beskæftigelse, eller hvilken sammenhæng der er mellem borgerens kvalifikationer og den opnåede position på arbejdsmarkedet. 
6. 1) tilbuddet ikke kan anses for et rimeligt tilbud på grund af forhold, der vedrører tilbuddets indhold,

2) den pågældende ikke kan arbejde på grund af sygdom, eller der er risiko for, at helbredet forringes, hvis det hidtidige arbejde fortsættes,

3) afstanden mellem bopæl og arbejdssted medfører en urimelig belastning af den pågældende på grund af transportvanskeligheder eller den tid, der går til transport,

4) den pågældende har ret til fravær ved graviditet, barsel og adoption, i det omfang der under fravær efter bestemmelserne i barselslovens $\S 6$, stk. 1 og $2, \S 7$, § 8, stk. $1-6$ og 8, § 9, § 13 og § 14, stk. 1 og 2 , er ret til dagpenge ved graviditet, barsel og adoption,

5) den pågældende er nødt til at passe sine børn, og der ikke kan anvises anden pasningsmulighed,

6) den pågældende modtager støtte efter lov om social service til pasning af handicappet barn eller døende nærtstående eller efter lov om ret til orlov og dagpenge ved barsel til pasning af alvorligt sygt barn,

7) den pågældende er omfattet af en friperiode efter $\S 23$ i lov om en aktiv beskæftigelsesindsats,

8) den pågældende aftjener værnepligt,

9) arbejdet er omfattet af en overenskomstmæssig konflikt eller

10) arbejdet omfatter udvikling og fremstilling af krigsmateriel.

7 I reglerne hedder det, at afvisning af eller udeblivelse i betydeligt omfang fra tilbud sanktioneres med ophør af hjælp. Og at kommunen kan beslutte, at hjælpen skal tilbagebetales for en måned med gentagne overtrædelser af rådighedspligten. Bemærk dog, at både tilbagebetaling og ophør af hjælp også var med i sanktionslovgivningen før 2009.

8 I loven hedder det, at "Hjoelpen kan alene ophøre, så loenge muligheden for at benytte et åbent tilbud består. Det er ikke et krav, at det er det tilbud, den pågoeldende udebliver fra, der skal voere mulighed for at benytte igen. Det er tilstraekkeligt, hvis personen kan møde op i et andet tilbud".

\section{RefERENCER}

AGENDA (2011): Kommuner straffer ledige vidt forskelligt, i Arbejdsmarkedspolitisk analyse, 28. april 2011, 1-2.

Ankestyrelsen (2011): Kontanthjoelp og sanktioner, Praksisundersøgelse, januar 2011.

Arbejdsdirektoratet/Qureshi, A. (2010): The Effect of Punitive Sanctions on the Transition Rate from Welfare to Work - an empiriacl analysis of the Danish labour market, Speciale, Qureshi 2009, København, Arbejdsmarkedsdirektoratet.

Arbejdsmarkedsstyrelsen (2009): Ny match model - hvorfor og hvordan?, Notat, December 2009.

Arbejdsmarkedsstyrelsen (2011a): Mail fra Arbejdsmarkedsstyrelsen 19. maj 2011 med svar på spørgsmålet "Hvilke paragraffer kan personer, der modtager kontanthjoelp eller starthjoelp, og som er indplaceret i matchgruppe 3, sanktioneres efter?"

Arbejdsmarkedsstyrelsen (2011b): Afbureaukratisering af rådigheds- og sanktionsregler. Udarbejdet for Arbejdsmarkedsstyrelsen af Slotsholmen analyse og kommunikation om velfærd. http://www.ams.dk/Presse/ Nyheder/2011/08-12-Rapport-om-afbureaukratisering.aspx

Bourdieu, Pierre (1996): Understanding, i

Theory, Culture and Society, 13, 2, 17-37.

Brunsson, Nils (1993): Ideas and Actions:

Justification and Hypocrisy as Alternatives

to Control, i Accounting, Organizations and Society, 18, 6, 489-506.

Brunsson, Nils (1989/2002): The Organization of Hypocrisy. Talk, Decisions and Actions in Organization, Copenhagen Business School Press.

Caswell, Dorte (2005): Handlemuligheder i socialt 
arbejde - et casestudie om kommunal frontlinjepraksis på beskaeftigelsesområdet, Ph.d.afhandling, Roskilde Universitet og AKF.

Caswell, Dorte \& Bodil Damgaard (2006):

Strukturreformens ømme tæer - hvor klemmer skoen på beskæftigelsesområdet? i Tidsskrift for Arbejdsliv, 8, 4, 45-61.

Caswell, Dorte, Greg Marston \& Jørgen Elm Larsen (2010): Unemployed citizen or 'at risk' client? Classification systems and employment services in Denmark and Australia, i Critical Social Policy, 30(3), 384-404.

Caswell, Dorte m.fl. (under udgivelse): Når kassen smoekkes $i$ - analyser af økonomiske sanktioner over for kontanthjoelpsmodtagere, København, AKF.

Danske Kommuner (2011): Flere ledige rammes på pengepungen, 14, 40-42.

Ejrnæs, Morten, Henning Hansen \& Jørgen Elm Larsen (2010): Levekår og coping - ressourcer, tilpasning og strategi blandt modtagere af le laveste sociale ydelser, København, CASA.

Hasenfeld, Yeheskel, Toorjo Ghose \& Kandyce Larson (2004): The Logic of Sanctioning Welfare Recipients: An Empirical Assessment, i Social Service Review, 78, 2, 304-319.

Høybye-Mortensen, Matilde (2011): Velfoerdsstatens dørvogtere, Ph.d.-afhandling, Københavns Universitet, Statskundskab.

KL (2010): Arbejdsdeling mellem jobcentret og den $\emptyset$ vrige kommunale forvaltning, Notat 7. juni 2010.

Larsen, Flemming m.fl. (2001): Kommunal aktivering: mellem disciplinering og integration, Aalborg Universitetsforlag.

Lipsky Michael (1980): Street-Level Bureaucracy: Dilemmas of the Individual in Public Services,
New York, Russell Sage Foundation.

Lødemel, Ivar \& Heather Trickey (2001): An offer you can't refuse. Workfare in international perspective, Bristol, Policy Press.

Madsen, Mikkel Bo, Marie Dam Mortensen \& Anders Rosdahl (2006): Arbejdsmarkedsparat eller ej? En kvalitativ analyse af visitationen of kontanthjoelpsmodtagere i ti kommuner, SFI.

Rothstein, Bo (1994): Vad bör staten göra, Stockholm, SNS Förlag.

Stake, Robert (2003): Case studies, i N.K. Denzin \& Y.S. Lincoln (red.): Strategies of qualitative inquiry (2nd ed.), Thousand Oaks, CA, Sage, 134-164.

Svarer, Michael (2007): The Effect of Sanctions on the Job Finding Rate: Evidence from Denmark, (http://ideas.repec.org/p/aah/aarhec/2007-10.html).

Svarer, Michael (2010): The Effect of Sanctions on Exit from Unemployment: Evidence from Denmark in Economica, (first published online 12 May 2010), 1-28.

Torfing, Jacob (2004): Det stille sporskifte i velfoerdsstaten. En diskursteoretisk beslutningsprocesanalyse, Århus, Aarhus Universitetsforlag.

Van den Berg m.fl. (2004): Punitive sanctions and the transition rate from welfare to work, Journal of Labour Economics, 22, 1, 211-241.

VEJ (2010): Vejledning om rådighed og sanktioner for personer, der ansøger om eller modtager kontanthjoelp eller starthjoelp, (https:// www.retsinformation.dk/Forms/R0710. aspx?id=131527)

Yin, R.K. (2003): Case Study Research - Design and Methods, 3rd edition, California, Sage Publications.

Dorte Caswell, cand.mag., ph.d., programleder i AKF

e-mail: doc@akf.dk

Matilde Høybye-Mortensen, cand.scient.soc., ph.d., forsker i AKF

e-mail: mhm@akf.dk 